\title{
Chemically Induced Mutagenesis in Sesamum indicum
}

\author{
R. Kumar* and N. Shunmugavalli \\ Department of Plant Breeding and Genetics, Tamil Nadu Agricultural University, Agricultural \\ College and Research Institute, Killikulam, Vallanad-628252, Tamil Nadu, India \\ *Corresponding author
}

\begin{tabular}{|c|c|}
\hline \multicolumn{2}{|r|}{ A B S T R A C T } \\
\hline & \multirow{6}{*}{$\begin{array}{l}\text { The present investigation was carried out to study the extent of variability existed in the } \\
\text { sesamum varieties namely TMV } 4 \text {, TMV } 7 \text {, VRI } 2 \text {, Thilak and TNY Local after induction } \\
\text { of mutation through chemical mutagens namely EMS. The results of } \mathrm{M}_{1} \text { generation } \\
\text { revealed that there was a shift in the mean for the characters Viz., Days to first flowering, } \\
\text { Plant height, Number of branches per plant, Number of capsules per plant, Length of } \\
\text { capsule, Number of seeds per capsule, Seed yield per plant, 1000-seed weight and Oil } \\
\text { content towards positive /negative directions. In } \mathrm{M}_{2} \text {, chlorophyll mutants namely, albina, } \\
\text { xantha, chlorine, viridis and few viable mutants like giant plant, bushy plant, unifolitat } \\
\text { leaf, narrow leaf, crinkled leaf, short capsule, black seeded, sterile plant and pigmented } \\
\text { mutants were recorded figures } 1 \text { and } 2 \text {. A significant increase in number of plant height, } \\
\text { number of capsule per plant, number of seed per capsule and seed yield per plant was } \\
\text { noticed in } \mathrm{M}_{2} \text { generation. The PCV and GCV showed significantly higher values in yield } \\
\text { component characters such as number of capsule per plant, number of seed per capsule, } \\
\text { Length of capsule and seed yield per plant in } \mathrm{M}_{2} \text { generation. The yield attributing traits } \\
\text { like number of capsule per plant, number of seed per capsule, Length of capsule and 1000- } \\
\text { seed weight recorded high heritability coupled with high genetic advance as per cent of } \\
\text { mean in } \mathrm{M}_{2} \text { generation. }\end{array}$} \\
\hline & \\
\hline $\begin{array}{l}\text { Chem } \\
\text { EMS, } \\
\text { mutag }\end{array}$ & \\
\hline Article Info & \\
\hline $\begin{array}{l}\text { Accepted: } \\
\text { 23 July } 2017 \\
\text { Available Online: } \\
\text { 10 September } 2017\end{array}$ & \\
\hline & \\
\hline
\end{tabular}

\section{Introduction}

Sesame, an important oil-yielding crop is a popular cooking medium used throughout India. The crop demonstrates good promise in the State of West Bengal also, because of higher productivity than national average. India ranks low in sesame productivity mainly due to dearth of high yielding varieties. Narrow gene pool in the available germplasms demands the need of crop restructuring for higher productivity. On the other hand, development of superior varieties may foster higher production of sesame in the country both through horizontal and vertical expansion and can obviously narrow down the huge demand-supply gap of oilseeds. Creation of variability transpires to be primary step to get desirable types. Mutation breeding has long been known as a potential technique to unlock additional genetic variability for supplementing conventional crop breeding methodology. Mutagenesis offers a unique scope for creating variation, as it may alter even those genes that are common to all the varieties of a species. Induced mutation has been extensively and successfully used for the improvement of 
many crops including oilseed crop like sesame (Das and Haque 1997, Li and Chen 1998, Mehta and Singh 1998, Sorour et al., 1999, Govindarasu and Ramamoorthi 2000, Sheeba et al., 2003, 2005, Chowdhury et al., 2009, Diouf et al., 2010, Begum and Dasgupta 2010, 2011, 2014). Creation of variability through pollination and artificial hybridization is very difficult and very delicate to handle. Even if hybridization is carried out the seed set is less than 5 per cent. Also, this crop lacks proper male sterility system commercially to be utilized for hybridization. Hence, the present investigation aims at creation of variation through induction of mutation through chemical mutagens.

\section{Materials and Methods}

Five sesamum genotypes namely, TMV 4, TMV 7, VRI 2, Thilak and TNY Local were selected to study the effect of chemical mutagenesis to induce variability in biometrical and morphological characters. The study was carried out at the plant breeding farm, Department of Plant Breeding and Genetics, Agriculture College and Research Institute during the year 2014-2016. Chemical mutagens like EMS were used for inducing mutation in sesamum. Ten sets containing 350 well filled seeds were selected for treatment. Seeds were soaked in water for three hours. Then soaked seeds were treated with EMS for eight hours. After soaking the seeds in the chemical, they were thoroughly washed under tap water 3-5 times. The seeds were then subjected to germination test. Based on the effect of chemical on germination, LD 50 was obtained. Three concentrations namely $0.7,1.0$ and 1.4 per cent were fixed for EMS treatment. After the treatments the seeds were thoroughly washed in tap water for eight to ten times. The seeds subjected to treatment were sown in the field along with control in Randomized Block Design with three replications. A total of 100 seeds were sown in each treatment. All the treatments including the control were raised in the field with a spacing of $30 \mathrm{~cm}$ between row and $15 \mathrm{~cm}$ between plants within rows. Nine morphologically distinct mutants which were identified in $\mathbf{M}_{1}$ generation in both the genotypes at the rate of five plants per treatment along with control were advanced to $\mathrm{M}_{2}$ generation. In $\mathrm{M}_{2}$ population 7518 from VRI 2, 22 from TMV 4, 10 from TMV 7, 15 from Thilak and 10 from TNY Local along with control were raised. Out of $75 \mathrm{M}_{2}$ population, only 21 population recorded high flowering and more pod set and ultimately high yield. Therefore ten mutant population viz, 0.7 per cent EMS of VRI 2 population 1, 1.0 per cent EMS of TMV 4 population 2 and 1.4 per cent EMS of TMV 7 population 3 were advanced to further studies. Biometric observations such as seed germination, plant survival, days to first flowering, plant height, Number of branches per plant, number of capsules per plant, length of capsule, Number of seeds per capsule, seed yield per plant, 1000-seed weight and Oil content were recorded. Various statistical parameters like PCV, GCV, Heritability and genetic advance as per cent of mean were calculated $\mathrm{inM}_{2}$ generation for various economic characters studied.

\section{Results and Discussion}

In the present investigation a wide spectrum of chlorophyll mutants was observed in the $\mathrm{M}_{2}$ mutagenic populations. Chlorophyll mutants like albina, xantha, chlorina and viridis were observed maximum at population 1 (Fig. 1). However the frequency of chlorina mutants was found to be low. This may be due to zygotic inviability. Similar results were reported by Singh et al., (1987) and Ilayaraja (2002). Also, a wide spectrum of viable mutants was observed in $\mathbf{M}_{2}$. The spectrum of viable mutants were plant type giant bushy, narrow leaf, crinkled leaf, glabrous leaf, long capsule and black colour seed. 
Int.J.Curr.Microbiol.App.Sci (2017) 6(9): 2172-2178

Fig.1 Chlorophyll mutant observed in VRI 2

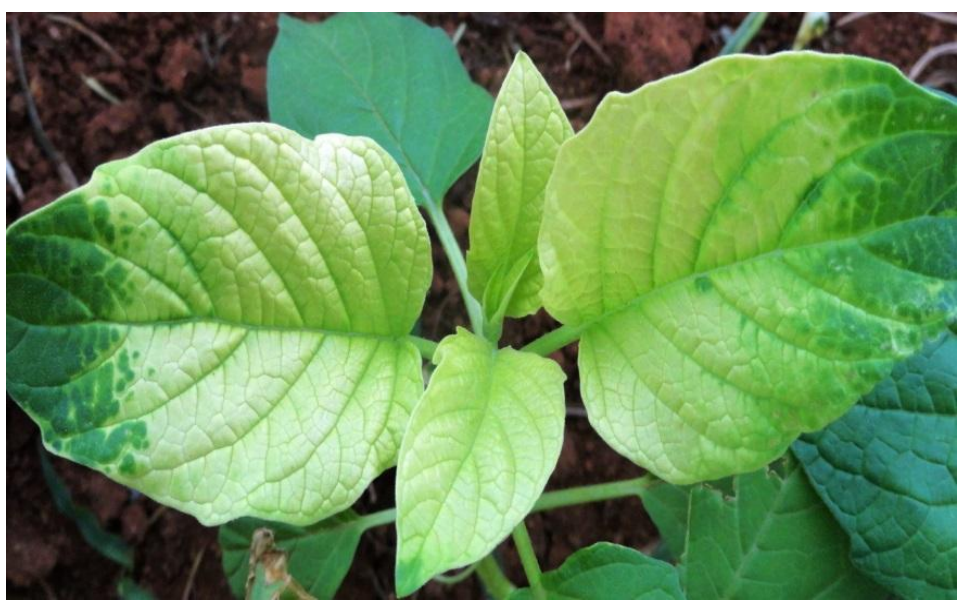

Chlorina VRI 2-1.0\%

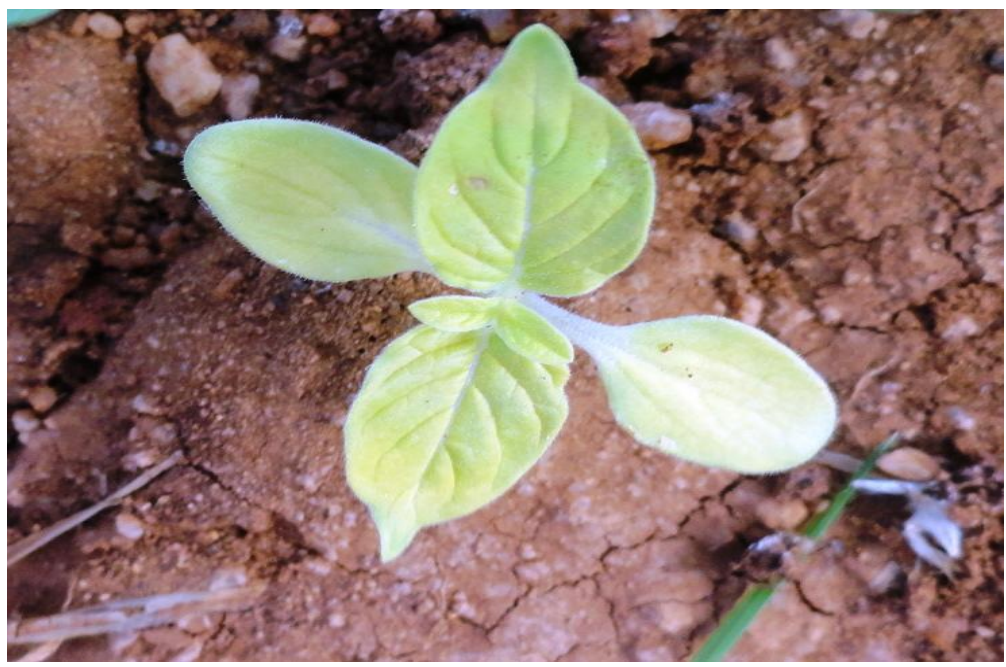

Xantha VRI 2- 1.0\%

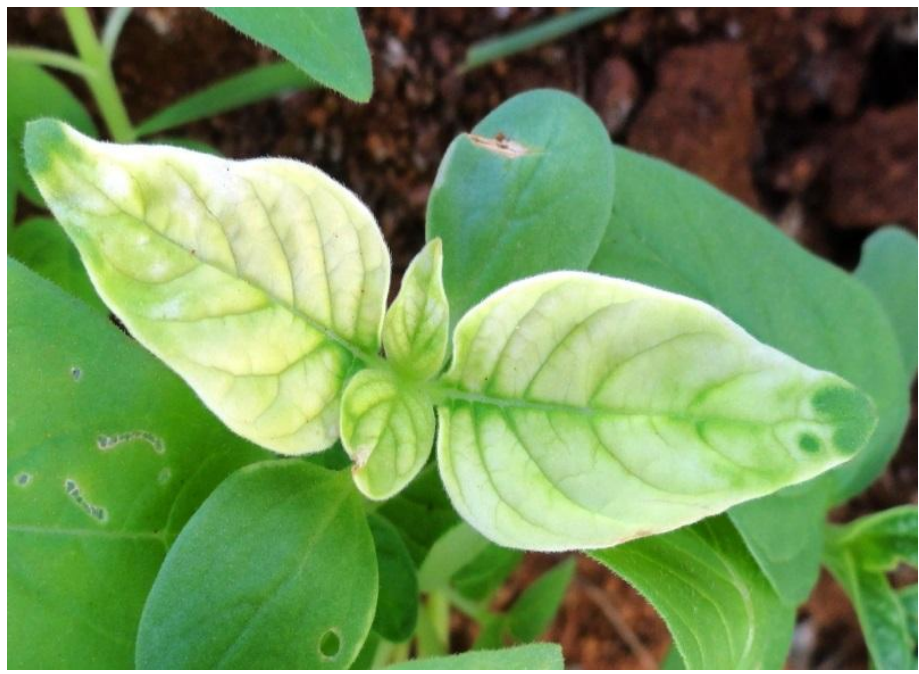

Xantha Viridis VRI 2- 1.0\% 
Fig.2 Sterile plants observed in two genotypes of $\mathrm{M}_{2}$ generation of sesamum

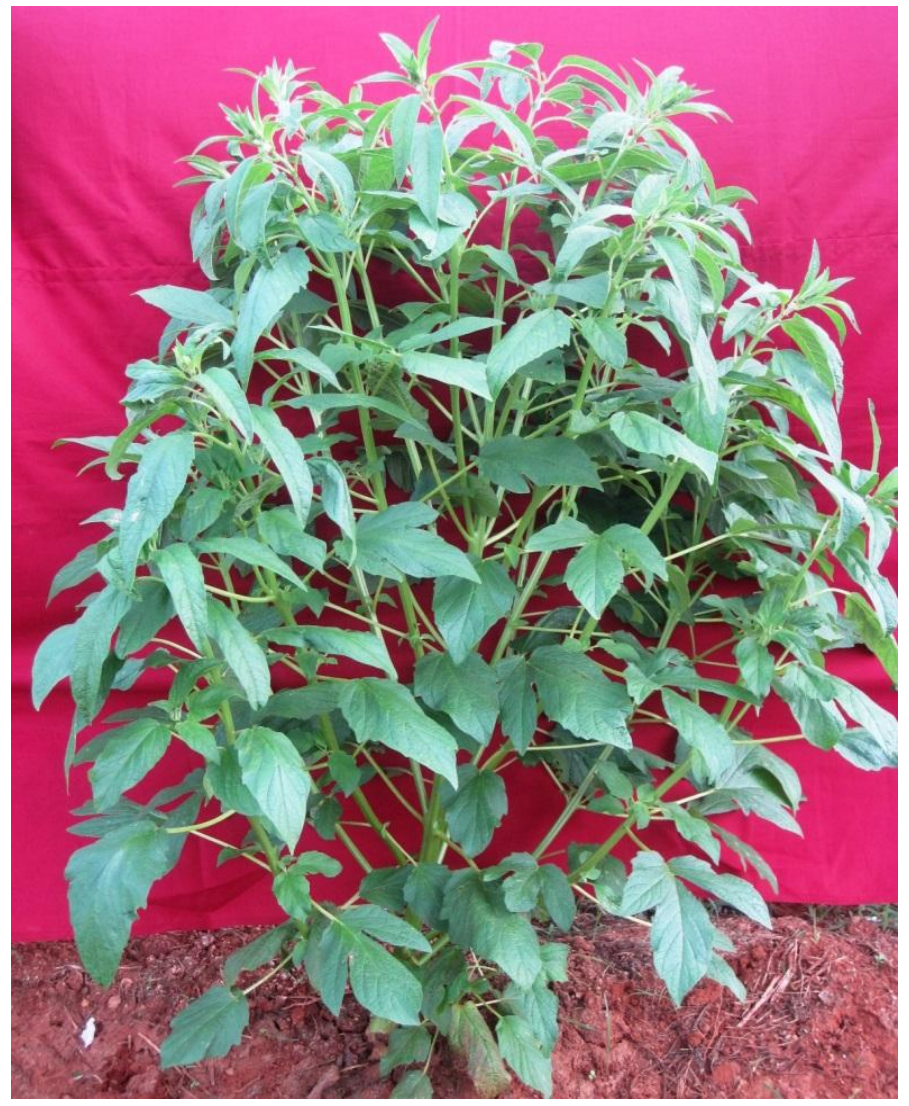

Table.1 Mean performance for number of capsule per plant in $\mathrm{M}_{2}$ generation of sesamum

\begin{tabular}{|c|c|c|c|c|c|c|c|c|c|c|}
\hline \multirow[b]{2}{*}{$\begin{array}{l}\text { Mutagens } \\
\text { Dose/Conc. }\end{array}$} & \multicolumn{5}{|c|}{ Number of capsule per plant } & \multicolumn{5}{|c|}{ Per cent change } \\
\hline & $\begin{array}{c}\text { TMV } \\
4\end{array}$ & $\begin{array}{c}\text { TMV } \\
7\end{array}$ & VRI 2 & Thilak & $\begin{array}{l}\text { TNY } \\
\text { Local }\end{array}$ & $\begin{array}{c}\text { TMV } \\
4\end{array}$ & $\begin{array}{c}\text { TMV } \\
7\end{array}$ & $\begin{array}{c}\text { VRI } \\
2\end{array}$ & Thilak & $\begin{array}{l}\text { TNY } \\
\text { Local }\end{array}$ \\
\hline & & & & & & & & & & \\
\hline & 8.49 & & & 25.45 & 180 & & & & & \\
\hline & & & & & & & & & & \\
\hline & & & & & & & & & & \\
\hline 1.4 & 109.13 & 59.84 & 97.73 & 77.23 & 107.62 & -0.59 & 48.27 & 19.10 & 38.44 & 0.0 \\
\hline
\end{tabular}

Table.2 Mean performance for single plant yield in $\mathrm{M}_{2}$ generation of sesamum

\begin{tabular}{|c|c|c|c|c|c|c|c|c|c|c|}
\hline \multirow{2}{*}{$\begin{array}{l}\text { Mutagens } \\
\text { Dose/Conc. }\end{array}$} & \multicolumn{5}{|c|}{ Single plant yield g } & \multicolumn{5}{|c|}{ Per cent change } \\
\hline & $\begin{array}{c}\text { TMV } \\
4\end{array}$ & $\begin{array}{c}\text { TMV } \\
7\end{array}$ & $\begin{array}{c}\text { VRI } \\
2\end{array}$ & nilak & $\begin{array}{l}\text { TNY } \\
\text { Local }\end{array}$ & TMV 4 & TMV 7 & VRI 2 & Thilak & $\begin{array}{l}\text { TNY } \\
\text { Local }\end{array}$ \\
\hline & & & & & & & & & & \\
\hline & & & & & & 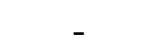 & - & - & - & - \\
\hline 0.7 & 12.78 & $1^{\prime}$ & 7. & 2 & 18. & 45. & 229. & 21.3 & 28.60 & \\
\hline 1 & 9.84 & 13.67 & 5. & 9 & 14.77 & & -15 & & 54.05 & -108.03 \\
\hline 1.4 & 7.01 & 9.15 & 3.40 & 6.12 & 10.89 & 25.82 & -72.64 & 44.26 & 74.47 & -53.38 \\
\hline
\end{tabular}


Table.3 Mutants exhibiting altered morphological traits observed in $\mathrm{M}_{2}$ generation of VRI 2 of sesamum

\begin{tabular}{|c|c|c|c|c|}
\hline \multirow{2}{*}{ Characters } & \multirow{2}{*}{ Classification } & \multirow{2}{*}{$\begin{array}{l}\text { Number of mutant } \\
\text { progenies identified }\end{array}$} & \multicolumn{2}{|c|}{ Phenotypic value } \\
\hline & & & Thilak & Mutants \\
\hline Monostem & & 8 & 3 - 4 branches & Single stem \\
\hline Flowering & Early & 5 & 35 days & 28 days \\
\hline Plant height $\mathrm{cm}$ & Dwarf plant & 5 & $105^{\circ}-x$ & $76-82$ \\
\hline $\begin{array}{l}\text { Mutant with high } \\
\text { yield g }\end{array}$ & & 4 & $4.20-5.20$ & 9.40 \\
\hline & Black & 8 & $\begin{array}{l}\text { Normal } \\
\text { Brown }\end{array}$ & Black \\
\hline Seed colour & Dark brown & 6 & $\begin{array}{l}\text { Normal } \\
\text { Brown }\end{array}$ & Dark brown \\
\hline & Light brown & 9 & $\begin{array}{l}\text { Normal } \\
\text { Brown }\end{array}$ & Light brown \\
\hline Sterile plant & & 3 & $\begin{array}{l}\text { Normal } \\
\text { Brown }\end{array}$ & Sterile \\
\hline
\end{tabular}

Table.4 Mean variability and heritability estimates for single plant yield in $\mathrm{M}_{2}$ generation of TMV 4, TMV 7, VRI 2, Thilak and TNY Local

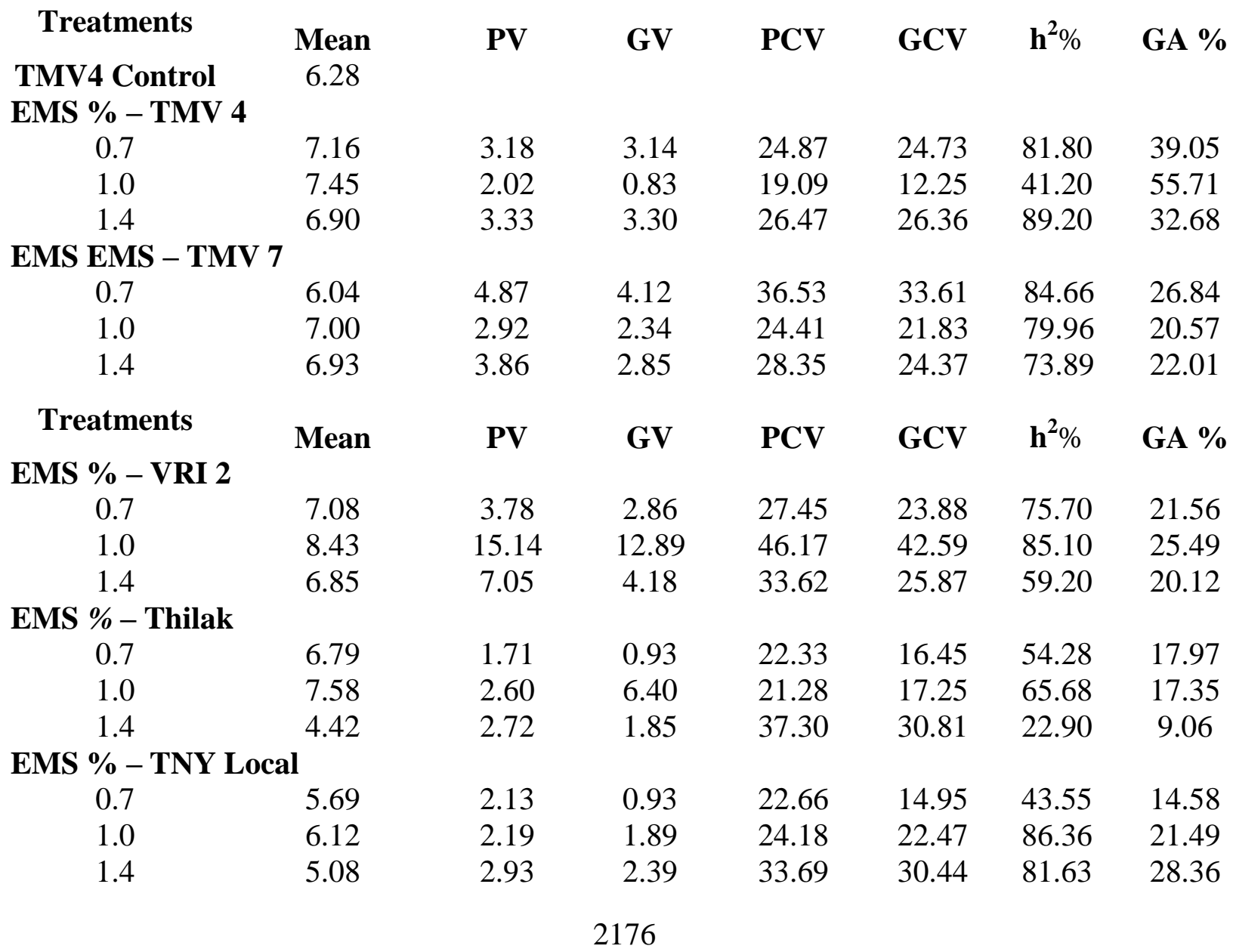


The narrow leaf mutants were mostly observed in population 4 (Table 3 ). The gene responsible could be nil. Pigmentation was observed in leaf, stem, pods and seeds. The gene that is responsible for pigmentation may be $\mathrm{R}$ gene complex. Similar mutants were observed by Gautam and Mittal (1998) in their studies on black gram. In the present study 1.0 per cent EMS of VRI 2 population 1 was found to be more effective than other populations. According to Konzak et al., 1965, the greater efficiency of low concentration of mutagen appeared in relation to the fact that lethality and injury increase with increase in concentration at faster rate than mutations. On the basis of lethality and injury the efficiency was more in the population 1 VRI 2 which was treated with 1.0 per cent EMS. It is also noted that the mean for different characters shifted both in positive and negative directions due to mutagenic treatments. Such a shift in mean on both the directions is influenced by the trait, genotype and dose of mutagen (Juliet Hepziba and Subramanian, 1994; Ilayaraja, 2002). The mutant with positive in one or more yield component characters resulted in high yielding mutant in sesamum. The trait capsule length, number of seeds per capsule and seed yield per plant showed positive shift of mean and increased range of mean on both the directions. The maximum shift towards the positive direction was observed by population 1 followed by population 4 of $\mathrm{M}_{2}$ generation. Similar shift towards the positive direction was observed by Malik et al., (1998), Charumathi et al., (1992) and Pawar et al., (1988). The positive shift in mean values of both the characters indicated that there was scope for improvement and the parental materials were the potential source in this respect (Table 1). Variation in growth parameters is essential for the selection of productive lines. The variability in quantitative characters increases considerably by treating the biological material with different mutagenic agents. Heritability estimates along with GA as per cent of mean are normally more helpful in predicting the gain under selection than heritability estimates alone. In the present study, significant variation has been observed in the mutant population for capsule length per plant and seed yield per plant. Variation in the treated population in $\mathrm{M}_{2}$ where population is heterozygous and heterogenous may be caused in one or a set of characters by point mutations, by enhancing the recombination rate and by chromosomal damage so as to release the total variability in blocks of linked genes (Table 3). This offers the same advantage as generally expected from intermating in early segregating generations Katoch et al., (1992). High to Moderate GCV and moderate heritability and genetic advance was noted for seed yield per plant and number of pods per plant (Table 4). The reason for this variability by irradiation was suggested as increased mutation and recombination of polygenes Juliet Hepziba and Subramanian (1994). It is noted that the population 1 of $\mathrm{M}_{2}$ recorded high GCV, PCV, heritability and genetic advance for both the characters viz., number of capsule per plant and seed yield per plant. Hence, mutants isolated with high mean, high heritability and GA as per cent of mean for these traits viz., number of capsule per plant and seed yield per plant may be useful in utilizing them in crop improvement programme.

\section{References}

Begum, T., and Dasgupta T 2014. Induced genetic variability, heritability and genetic advance in sesame Sesamum indicum L. SABRAO J. Breed. Genet. 46: 21-33.

Begum, T., and Dasgupta T. 2010. A comparison on the effect of physical and chemical mutagenic treatments in sesame Sesamum indicum L. Genet. 
Mol. Biol. 33: 761-766.

Begum, T., and Dasgupta T. 2011. Effect of mutagens on character association in sesame Sesamum indicum L. Pak. J. Bot. 43: 243-251.

Kumar, R., and N. Shunmugavalli. 2016. Gamma rays and EMS induced flower colour and seed mutants in sesame
Sesamum indicum 1.

Pawar, S.E., R.G. Thakare and C.R.Bhatia.1988.Genetic improvement of Pulse crops. Induced mutations and their use in cross breeding improvement of grain legume production using induced mutations, IAEA, Vienna, pp. $235-249$.

\section{How to cite this article:}

Kumar, R. and Shunmugavalli, N. 2017. Chemically Induced Mutagenesis in Sesamum indicum. Int.J.Curr.Microbiol.App.Sci. 6(9): 2172-2178.

doi: https://doi.org/10.20546/ijcmas.2017.609.267 